\title{
Taxonomy
}

\section{A new class of echinoderms}

\section{from David Nichols}

WATERLOGGED wood often sinks down to the deep sea-bed, to become an oasis of solidity in a vast expanse of sediment. Its crevices, filled with a soup of bacteria, become a haven for tiny organisms, including, it now emerges, a hitherto unknown echinoderm. So specialized are these 'sea-daisies' that a new class, the Concentricycloidea, has been erected to contain them. An article on page 862 of this issue describes the new genus, Xyloplax.

In August 1985, three echinoderm specialists, Alan Baker, Helen Clark and Frank Rowe, met at the National Museum of New Zealand principally to compare species of starfish common to waters off New Zealand and New South Wales. A worker at the museum, Bruce Marshall, was investigating gastropods from crevices in driftwood from a depth of $1,000 \mathrm{~m}$ and had put aside capsules with fragments or whole specimens of small caymanostellid starfishes for Rowe to examine during his visit. Sharing the capsules were nine specimens of a tiny animal, clearly an echinoderm, which Rowe and his colleagues could not place in any known group.

The disk-shaped body of the echinoderm is supported by a series of circumferential rings of plates (see Fig. 1) bearing a fringe of sub-phyum spines projecting like the petals of a daisy. The slightly domed dorsal integument contains scale-like plates that imbricate like roofing tiles, and each plate bears several stunted spines. Also visible on top are five large plates equally spaced around the periphery, representing the homologues of the plates at the armtips in starfishes, or those at the top of the radial columns (the so-called 'ambulacra') in sea-urchins.

Towards the circumference on the underside is a ring of hydraulic tube-feet projecting downwards. Each is apparently operated by a bag-like ampulla situated within the body, and all are connected externally by a water-vascular ring. Uniquely for echinoderms there is a second ring beside the first, and the two rings are connected by short inter-radial canals. In known echinoderms there is a functional need for confluence between the watervascular system and the outside sea water. so that the hydrostatic pressure in the system equates with that of the outside medium. In Xyloplax too, this connection is provided at a hydropore on the dorsal (ars) surface, connected to the inner watervascular ring.

The animal has no gut, which takes to the ultimate the reduction in gut feeding of other echinoderms. Some seacucumbers, for instance, feed for only part of the year, generally when energy uptake is increased before reproduction. For the rest of the year, the gut remains empty and the organisms rely on the free radicals in sea water, absorbed mainly through a velvet-like 'pile' of microvilli over the external body surface.

The concentricycloids are reported to have a thin velum, which stretches drum-like across the ventral surface, and, further, the tube-feet themselves are thought to have food storage coelomocytes within their lumina. It is interesting to speculate that the suspension of bacteria which share the wood crevices with these animals may aid the nutritional process in a manner similar to that in deep-water pogonophores, which contain symbiotic bacteria in special tissues within their bodies. Perhaps in concentricycloids some bacteria are held beneath the subumbrella surface, within the palisade of spines, the radicals they release diffusing through the velum to the interior.

Asterozoa Echinozoa

Concentricycloidea Echinoidea Holothuroidea

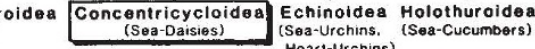

Ophiuroidea

(Britle-Stars.
Basket-Stars) Heart-Urehins)
Hea-Urchins

of echinoder

An exciting find is that the gonads of the animals contain embryos at various stages of development up to juveniles, which look like miniature adults. There are sound reasons for releasing young into the immediate vicinity of the adults when the 'parent' substrate is the only suitable habitat for a considerable distance. But timber, despite its slow decomposition in deep water, does not last for ever, and some mechanism is required for wider deployment of the offspring.

So long as the young concentricycloids are within the gonad, their peripheral spines are tucked under their bodies, but on release the spines open out, and are at this stage longer proportionally than the spines of the adult. This may be a flotation device to assist the juveniles to be carried above the sediment until they encounter another suitably pitted or creviced substrate.

As yet, it is possible to make only the most tentative proposals about relationships of the new class. Suggestions by the authors that Xyloplax resembles the cyclocystoids (an extinct class of subcircular echinoderms from the Middle Ordovician to Middle Devonian) may have been based on older reconstructions, now superceded by more detailed studies of almost all known cyclocystoid specimens (Smith, A.B. \& Paul, C.R.C. Phil. Trans. R. Soc. B296, 577; 1982).

Cyclocystoids had a marginal ring of hefty plates with two plate-supported membranes stretched within. But the membranes were closely associated,

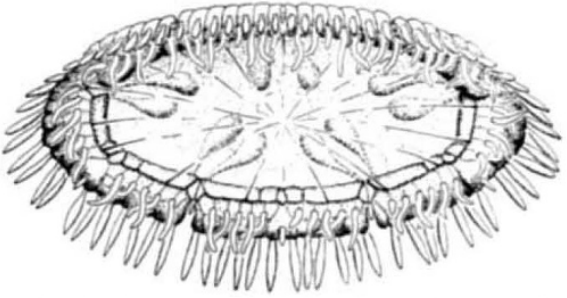

Fig. 1 Conjectural ventro-lateral view of Xyloplax medusiformis, a new concentricycloid from deep water off New Zealand.

dorsal to ventral, so that the organism would have resembled, as Smith and Paul put it, "a tambourine, not a drum", and the space between the membranes would have been very limited indeed, unlike the body-cavity in concentricycloids. Further, although earlier reconstructions (for example, Nichols, D. Palaeontology 15, $519 ; 1972$ ) suggested that a series of cupules in the marginal ring represent anchorages for a ring of tube-feet similar to the arrangement in Xyloplax, there are now grounds for rejecting this idea first, the cupules have tubercles within them; and second, they do not connect up with the most likely seat of the watervascular system, which provides fluid for tube-foot operation.

What, then, is the nearest known echinoderm relative of this new class? The authors suggest that it belongs to the Asterozoa, the sub-phylum that includes all starfishes and brittle-stars (see Fig. 2). This group already includes some pretty bizarre forms, such as the spherical starfish Podosphaeraster (Rowe, F.W.E., Nichols, D. \& Jangoux, M. Micronesica 18, 83; 1982; Rowe, F.W.E. Bull. Mus. natn. Hist. nat., Paris 7, 309; 1985).

In the case of Xyloplax, a feasible derivation of the marginal ossicles is suggested by the authors, who see the ambulacral tube-feet, normally in a double column and radially arranged, as if having splayed out laterally and come to abut against the adjacent column in a circle. Clearly, a considered proposal about relationships awaits more rigorous study of this animal than has so far been possible.

David Nichols is Professor of Biological Sciences at the University of Exeter, Exeter EX 4 4PS, UK. 